\title{
Assigning king eiders to wintering regions in the Bering Sea using stable isotopes of feathers and claws
}

\author{
Steffen Oppel ${ }^{1, *}$, Abby N. Powell ${ }^{2}$ \\ ${ }^{1}$ Department of Biology and Wildlife, 211 Irving 1, University of Alaska, Fairbanks, Alaska 99775-6100, USA \\ ${ }^{2}$ U.S. Geological Survey, Alaska Cooperative Fish and Wildlife Research Unit, and Institute of Arctic Biology, \\ 209 Irving I., University of Alaska, Fairbanks, Alaska 99775-7020, USA
}

\begin{abstract}
Identification of wintering regions for birds sampled during the breeding season is crucial to understanding how events outside the breeding season may affect populations. We assigned king eiders captured on breeding grounds in northern Alaska to 3 broad geographic wintering regions in the Bering Sea using stable carbon and nitrogen isotopes obtained from head feathers. Using a discriminant function analysis of feathers obtained from birds tracked with satellite transmitters, we estimated that $88 \%$ of feathers were assigned to the region in which they were grown. We then assigned 84 birds of unknown origin to wintering regions based on their head feather isotope ratios, and tested the utility of claws for geographic assignment. Based on the feather results, we estimated that similar proportions of birds in our study area use each of the 3 wintering regions in the Bering Sea. These results are in close agreement with estimates from satellite telemetry and show the usefulness of stable isotope signatures of feathers in assigning marine birds to geographic regions. The use of claws is currently limited by incomplete understanding of claw growth rates. Data presented here will allow managers of eiders, other marine birds, and marine mammals to assign animals to regions in the Bering Sea based on stable isotope signatures of body tissues.
\end{abstract}

KEY WORDS: Geographic assignment $\cdot$ Stable isotopes $\cdot$ Bering Sea $\cdot$ King eider $\cdot{ }^{13} \mathrm{C} \cdot{ }^{15} \mathrm{~N} \cdot$ Feather

\section{INTRODUCTION}

Events outside the breeding season can not only affect population numbers (Votier et al. 2005), but also influence the physical condition of migratory birds, and thus have the potential to affect their population dynamics (Webster et al. 2002, Newton 2006). For instance, events during the winter have been shown to affect body condition and reproductive performance of migratory birds (Marra et al. 1998, Bearhop et al. 2004, Norris et al. 2004). It is therefore important to identify the wintering areas of migratory birds in order to investigate such carry-over effects. This represents a challenge for marine birds wintering in remote areas at sea.
Stable isotope analysis of tissues has advanced the ability to investigate the migratory connectivity of breeding and wintering areas for several bird species (Hobson 1999, Webster et al. 2002, Gómez-Díaz \& González-Solís 2007). This technique relies on the assumption that birds incorporate the isotopic signature of the geographic area in which they forage during tissue formation. For biochemically inert keratinbased tissues, such as feathers and claws, the isotope signature does not change after growth is completed (Mizutani et al. 1992, Hobson 2005).

Sea ducks nesting in the Arctic generally winter in marine environments, where many grow body feathers of the alternate (breeding) plumage (Madge \& Burn 1988). Stable isotope analyses have been 
applied to infer the geographic location of wintering and molting areas of North American sea ducks (Mehl et al. 2005, Knoche et al. 2007). Due to recent decreases in sea duck populations, and the realization that factors operating on wintering grounds may affect sea duck populations (Lovvorn et al. 2003, Grebmeier et al. 2006), managers require reliable techniques to identify molting and wintering regions of duck populations that are monitored during the breeding season.

The king eider Somateria spectabilis is the most abundant Arctic sea duck, but populations in western North America have declined substantially between the 1970s and 1990s (Suydam et al. 2000). King eiders from breeding grounds in northern Alaska and western Canada migrate to wintering areas in the Bering Sea (Suydam 2000, Phillips et al. 2006), and population declines are presumably linked to ecosystem changes in the Bering Sea (Grebmeier et al. 2006). There are at least 3 distinct wintering regions used by king eiders in the Bering Sea, among which there is little or no movement of individuals during mid-winter (Oppel et al. 2008) (Fig. 1). These 3 regions differ in their physical properties, proximity to breeding areas, and extent of human use. These differences may therefore result, on average, in differing physical condition or survival of individuals using each region during winter. To examine breeding performance of individuals wintering in different regions, it is necessary to assign individuals to one of the wintering regions based on samples that can be obtained from breeding birds.

Spatial differences of stable isotope values exist in Bering Sea sediments (Naidu et al. 2000), benthic

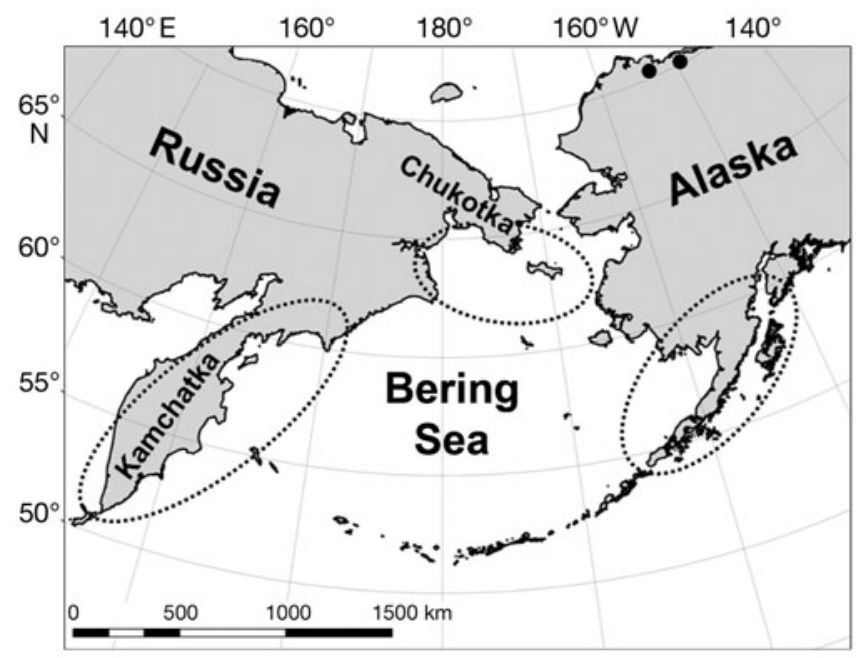

Fig. 1. Somateria spectabilis. Three distinct regions (dashed ovals) used by wintering king eiders in the Bering Sea as derived from satellite telemetry of 94 adult king eiders between 2002 and 2007. (•): Capture locations on breeding grounds organisms (Dunton et al. 1989), zooplankton (Schell et al. 1998), and in king eider primaries (Knoche et al. 2007). As king eiders forage on sessile benthic organisms by diving to the sea floor, isotopic differences inherent in a region's food web are likely to be reflected in king eider tissues. We hypothesized that the 3 regions used by king eiders in winter may be distinct in carbon and nitrogen isotope ratios of tissues grown in these regions.

Stable isotope ratios of head feathers, which are assumed to be grown on wintering areas, have been used to discern whether king eiders winter in the Atlantic or Pacific Oceans (Mehl et al. 2004, 2005). Molt of head feathers in king eiders is believed to start as early as October and might be completed by November (Suydam 2000). In the present study, we established a method to geographically assign birds to one of the 3 wintering regions in the Bering Sea using stable isotope ratios of head feathers. We used information obtained from satellite-tracked king eiders to isotopically delineate the 3 main regions in the Bering Sea. We then assigned feathers of birds not tracked with satellite transmitters to regions using their stable isotope signatures.

A vital component for the application of stable isotope analysis of feathers to infer geographic origin is a clear understanding of the molt cycle of the species in question. Recent analyses of satellite-tracked king eiders show that fall migration schedule is extremely variable, and that some king eiders may not arrive on their wintering grounds before they have completed their body molt (Oppel et al. 2008). It is thus possible that head feathers carry the isotopic signature of a molting or staging area, which may result in an incorrect assignment of birds to wintering areas based on their head feather isotopic signature. In contrast, claws grow continuously and claw tips may provide isotopic information from several months prior to collection (Bearhop et al. 2003, 2004). Our second objective was to explore whether claw tips collected from birds on the breeding grounds can be used as an alternative tissue that reflects the isotopic signature of the wintering region.

\section{MATERIALS AND METHODS}

Study area. We captured king eiders on breeding grounds on the Arctic coastal plain of Alaska at 2 study locations: (1) near Teshekpuk Lake $\left(70^{\circ} 26^{\prime} \mathrm{N}\right.$, $\left.153^{\circ} 08^{\prime} \mathrm{W}\right)$; and (2) in the Kuparuk oilfield $\left(70^{\circ} 20^{\prime} \mathrm{N}\right.$, $149^{\circ} 45^{\prime} \mathrm{W}$ ) (Fig. 1). From extensive satellite telemetry of 94 adult king eiders tracked from Alaska between 2002 and 2006, we found 3 discrete wintering regions in the Bering Sea: (1) the northern Bering Sea; 
(2) southwest (SW) Alaska; and (3) the Kamchatka coastline (Oppel et al. 2008) (Fig. 1). Each of these regions is a broad geographic unit that contains several localities where king eiders winter. Because movements of king eiders occurred within each region a finer spatial resolution was not practical.

Choice and collection of tissues. King eiders annually undergo complete flight feather molt, as well as 2 almost complete molts of body plumage. Flight feather molt is simultaneous and renders birds flightless for several weeks during August to October (Suydam 2000, Phillips et al. 2006). Timing and distance of migration to wintering sites after flight feather molt is highly variable (Oppel et al. 2008). Body feathers of the alternate plumage, which is worn through the breeding season in the following year, are molted some time after flight feathers, with high individual variation in both timing and extent of the molt (Suydam 2000). Claws grow continuously, and thus can provide an isotopic signal of a point in time prior to sampling that depends mostly on the length of the claw and its growth rate (Bearhop et al. 2003). Data on claw growth rates for sea ducks are currently unavailable, but experimentally determined claw growth rates for 3 species of captive waterfowl (mallard Anas platyrhynchos, pintail Anas acuta, and lesser scaup Aythya affinis) ranged from 0.06 to $0.13 \mathrm{~mm} \mathrm{~d}^{-1}$ (R. G. Clark unpubl. data). For king eider claws of 9 to $10 \mathrm{~mm}$ in length, these growth rates would result in isotopic information at the distal end $(\sim 1 \mathrm{~mm})$ of the claw from 70 to $170 \mathrm{~d}$ prior to capture. Claws from king eiders captured in June and early July would thus yield isotopic information from late December through early April. None of 94 satellite tracked king eiders wintering in the Bering Sea moved between wintering regions during this time period (Oppel et al. 2008). Isotopic food-tissue discrimination is similar between feathers and claws, and claws may therefore provide a similar isotope ratio as feathers if they were grown from the same diet and in the same region (Bearhop et al. 2003). We therefore chose head feathers to determine wintering regions of king eiders, and used the isotope ratio of claws to evaluate whether claw tips reflected the same region as head feathers.

We collected head feathers and claws of adult king eiders in June and early July 2005 to 2007 by capturing birds in nesting areas using mist nets. We collected head feathers from an additional 12 females during brood rearing in mid-August 2006 and 2007. We did not collect claws from birds captured after 20 July each year, as the claw tip isotope signature after that date would be unlikely to reflect wintering grounds. We plucked one head feather and clipped the apical $2 \mathrm{~mm}$ section of the central forward claw of either foot using a dog nail clipper. All tissues were collected under the
Institutional Animal Care and Use Committee protocol \#05-29 of the University of Alaska, Fairbanks.

Stable isotope analyses. We removed surface contaminants from all claws and feathers by rinsing them repeatedly in ethanol and scrubbing with cotton swabs (Knoche 2004). We removed the most apical section of the claw ( 0.5 to $1 \mathrm{~mm})$ which provided sufficient sample weight for isotopic analysis (0.2 to $0.4 \mathrm{mg})$. Claw material was homogenized and ground to a fine powder in an electrical mill. We analyzed claws and feathers for $\mathrm{C}$ and $\mathrm{N}$ stable isotope ratios at the Alaska Stable Isotope Facility at the University of Alaska, Fairbanks, using a continuous flow stable isotope-ratio mass spectrometer with a precision of \pm 0.14 and $\pm 0.06 \%$ for $\mathrm{C}$ and $\mathrm{N}$, respectively. Results of isotopic analyses are reported as ratios in delta notation relative to international standards (PeeDee Belemnite for $\mathrm{C}$, atmospheric air for $\mathrm{N}$ ) according to the following equation:

$$
\delta X=\left(\left[R_{\text {sample }} / R_{\text {standard }}\right]-1\right) \times 1000
$$

where $X$ denotes either ${ }^{13} \mathrm{C}$ or ${ }^{15} \mathrm{~N}$, and $R$ represents the ratio of ${ }^{13} \mathrm{C} /{ }^{12} \mathrm{C}$ or ${ }^{15} \mathrm{~N} /{ }^{14} \mathrm{~N}$, respectively. We report all isotope ratios as means $\pm \mathrm{SD}$.

Isotopic delineation of regions. We equipped 32 of the sampled adult king eiders (13 males, 6 females in 2005; 6 females in 2006; 7 females in 2007) with satellite transmitters, enabling us to track their movements throughout the following year (see Oppel et al. 2008 for details). Male and female eiders use identical wintering regions (Phillips et al. 2006, Oppel et al. 2008) and consume very similar diets at sea (Bustnes \& Erikstad 1988, Frimer 1997, Bustnes et al. 2000, Merkel et al. 2007a). We therefore did not expect isotope ratios of winter-grown feathers to differ by sex, and tested this assumption by comparing isotope ratios of head feathers between sexes within each winter region (see 'Results', Table 1).

We determined the location of each bird during winter using the data provided by satellite transmitters. All feathers we sampled from satellite tracked birds were grown in the year before we tracked the birds. Hence, in order to relate the isotopic information of feathers to geographic regions, we implicitly assumed winter region fidelity between years. This assumption was realistic due to the large size $\left(>10^{5} \mathrm{~km}^{2}\right)$ of the regions we distinguished (Robertson \& Cooke 1999). Further, king eiders display fidelity to molting areas (Phillips \& Powell 2006), and winter region fidelity has so far been found in all individuals in which the battery of the satellite transmitter lasted long enough to track birds for 2 subsequent winters ( $\mathrm{n}=11, \mathrm{~S}$. Oppel unpubl. data). Thus, we considered feathers collected from satellite-tracked birds to be of 'known origin'. We assigned stable isotope values of head feathers to one 
of the 3 regions in the Bering Sea where the bird was recorded during winter. We delineated the 3 main regions by separating clusters of data points from feathers assigned to the same region using a discriminant function analysis (DFA) with the stable isotope ratios of $\mathrm{C}$ and $\mathrm{N}$ of 32 head feathers (1 per tracked bird) as predictor variables. We did not use a maximum likelihood approach to infer geographic origin (Royle \& Rubenstein 2004), as prior information on the winter distribution of most birds in the Bering Sea is lacking, which limits likelihood-based approaches (Norris et al. 2006). We conducted DFA in SPSS ${ }^{\mathrm{TM}}$ 11.0, setting prior probabilities equal among regions. We present classification results as the number of feathers of known origin correctly classified in a cross-validation procedure, where each feather is tested for correct classification predicted from a DFA model constructed without that feather (Gómez-Díaz \& González-Solís 2007). We compared isotope ratios among the 3 regions using Kruskal-Wallis tests and $\alpha=0.05$.

Geographic assignment of tissues of unknown origin. The origin of feathers and claws was unknown for 94 birds (94 head feathers, 62 claws) captured on breeding grounds but not equipped with a satellite transmitter. We assigned the tissues of unknown origin to one of the 3 regions in the Bering Sea using the discriminant functions and the isotopic data for each tissue. Each tissue of unknown origin was assigned to the region for which it had the highest probability of membership. To increase confidence in assignments and reduce misclassifications we used an exclusion threshold of $75 \%$ on the posterior probability of membership, and excluded any tissue with a lower level of geographic assignment probability for each of the 3 regions (Wunder et al. 2005, Rocque et al. 2006). Based on head feather assignment, we calculated the proportion of birds wintering in each region. To assess the utility of claws as an indicator of wintering region, we compared winter region inferred from claw and head feather isotope ratios for individuals from which we had both claw and head feather with a $>75 \%$ assignment probability.

\section{RESULTS}

\section{Feathers of known origin}

We analyzed one winter-grown head feather from each of the 32 king eiders we tracked with satellite transmitters. Isotope ratios did not differ between male and female feathers in each winter region (all $p>0.6$, Table 1), and we pooled feathers from both sexes for further analysis. Feathers from birds that subsequently wintered in SW Alaska were enriched in ${ }^{15} \mathrm{~N}$ compared to feathers from birds wintering near Kamchatka and
Table 1. Somateria spectabilis. Isotope ratios $( \pm \mathrm{SD})$ of head feathers of 32 king eiders tracked with satellite transmitters from breeding grounds in northern Alaska to wintering regions in the Bering Sea. Geographic assignment of feathers to regions is based on the assumption of between-year site fidelity of satellite-tracked birds. See Fig. 1 for extent of regions

\begin{tabular}{|llccc|}
\hline Geographic region & Sex & $\mathrm{n}$ & $\delta^{13} \mathrm{C}(\%)$ & $\delta^{15} \mathrm{~N}(\%)$ \\
\hline North Bering Sea & Male & 5 & $-17.3 \pm 0.4$ & $14.9 \pm 1.0$ \\
& Female & 9 & $-16.8 \pm 1.2$ & $15.1 \pm 0.7$ \\
SW Alaska & Male & 3 & $-16.9 \pm 0.6$ & $17.3 \pm 1.0$ \\
& Female & 3 & $-17.0 \pm 0.7$ & $17.6 \pm 2.0$ \\
Kamchatka & Male & 5 & $-14.9 \pm 0.6$ & $13.9 \pm 1.1$ \\
& Female & 7 & $-15.1 \pm 1.0$ & $14.3 \pm 1.1$ \\
\hline
\end{tabular}

in the northern Bering Sea $(H=16.12, \mathrm{p}<0.001)$ (Table 1). In contrast, feathers from Kamchatka were enriched in ${ }^{13} \mathrm{C}$ compared to feathers from SW Alaska and the northern Bering Sea $(H=16.39, \mathrm{p}<0.001)$ (Table 1). A reliable assignment of a feather to one of the 3 regions would thus not be possible when using isotope ratios of only a single element (Fig. 2).

A DFA provided an accurate classification of these 32 feathers to the 3 major regions in the Bering Sea using 2 discriminant functions explaining 94.1 and $5.9 \%$ of the variance, respectively. The standardized canonical discriminant function coefficients for the 2 discriminant functions were -1.047 and 0.589 for $\delta^{13} C_{\text {, }}$ and 1.070 and 0.545 for $\delta^{15} \mathrm{~N}$, respectively. We classi-

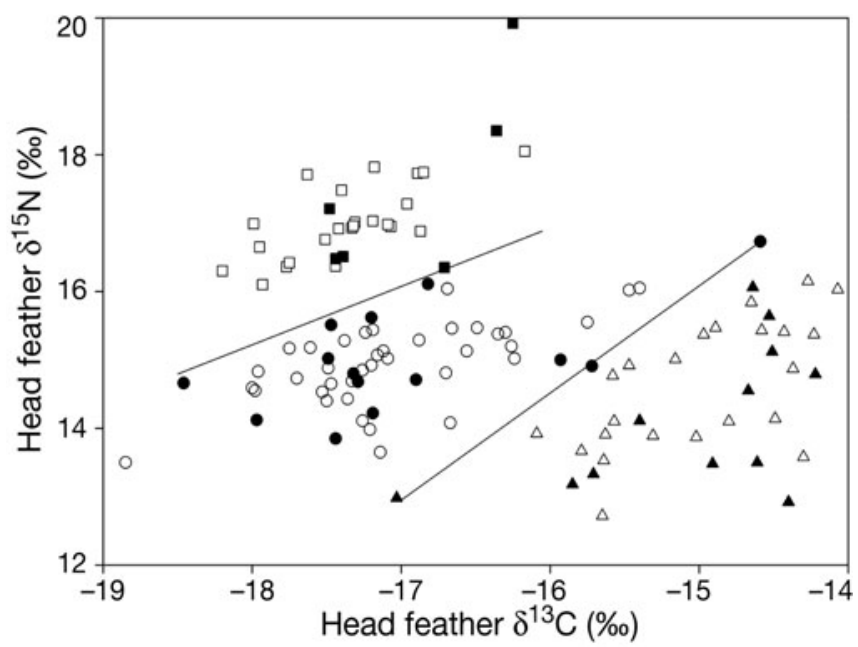

Fig. 2. Somateria spectabilis. Stable carbon and nitrogen isotope ratios of king eider head feathers collected from birds captured on breeding grounds in northern Alaska. Filled symbols: feathers from birds tracked with satellite transmitters; open symbols: tissues of unknown origin assigned to one of the 3 regions in the Bering Sea with $>75 \%$ probability using a discriminant function analysis. Solid lines: discriminant functions used for classification; $\mathbf{\square}, \square$ : SW Alaska;,$\bullet$ : North Bering Sea; $\Delta_{1} \mathbf{\Lambda}$ : coast of Kamchatka; see Fig. 1 for extent of regions 
Table 2. Somateria spectabilis. Isotope ratios $( \pm \mathrm{SD})$ of head feathers and claw tips of 84 king eiders captured on breeding grounds in northern Alaska. Feathers and claw tips were assigned to geographic regions using a discriminant function analysis based on feather samples presented in Table 1. All tissues presented here were assigned with a probability $>75 \%$. See Fig. 1 for extent of regions

\begin{tabular}{|c|c|c|c|c|c|c|}
\hline \multirow{2}{*}{$\begin{array}{l}\text { Geographic } \\
\text { region }\end{array}$} & \multicolumn{3}{|c|}{ Head feather } & \multirow{2}{*}{$\mathrm{n}$} & - Claw ti & \multirow{2}{*}{$p \overline{\delta^{15} \mathrm{~N}(\%)}$} \\
\hline & $\mathrm{n}$ & $\delta^{13} \mathrm{C}(\% \circ)$ & $\delta^{15} \mathrm{~N}(\%)$ & & $\delta^{13} \mathrm{C}(\%)$ & \\
\hline North Bering Sea & 38 & $-17.1 \pm 0.7$ & $14.9 \pm 0.6$ & 30 & $-17.4 \pm 0.8$ & $14.9 \pm 0.6$ \\
\hline SW Alaska & 23 & $-17.4 \pm 0.5$ & $17.0 \pm 0.5$ & 8 & $-17.1 \pm 0.9$ & $17.4 \pm 0.7$ \\
\hline Kamchatka & 23 & $-15.0 \pm 0.6$ & $14.6 \pm 0.9$ & 15 & $-15.2 \pm 0.3$ & $14.1 \pm 0.7$ \\
\hline
\end{tabular}

fied $87.5 \%(n=28)$ of the 32 feathers of known origin correctly in cross-validation using 2 discriminant functions. Four feathers were assigned to a geographic region different than the one used by the respective bird in the subsequent winter. These feathers had assignment probabilities of $<60 \%$ to any region. Applying an exclusion threshold of $75 \%$ assignment probability resulted in the exclusion of 6 feathers $(19 \%)$, and correct classification of all remaining feathers $(n=26)$. Parameters required to reconstruct this model and apply it to data of unknown origin are available from the authors upon request.

\section{Feathers and claws of unknown origin}

We analyzed 94 head feathers and 62 claws from 94 birds of unknown origin. We assigned each feather and claw to one of the 3 regions in the Bering Sea using their $\delta^{15} \mathrm{~N}$ and $\delta^{13} \mathrm{C}$ and the 2 discriminant functions (Table 2, Fig. 2). Ten head feathers (11\%) and 9 claws (15\%) had classification probabilities of $<75 \%$ to any region and were excluded from further analysis.

Based on reliably assigned head feathers of 84 birds, $27 \%$ of king eiders wintered in SW Alaska, $45 \%$ in the northern Bering Sea, and $27 \%$ along the coastline of Kamchatka. For 48 of these birds (6 males, 42 females) we were able to compare the geographic assignment to a wintering region based on reliable assignments from claws and head feathers. Claws and head feathers were assigned to identical regions for 33 birds (69\%). In 15 birds the claw was either assigned to a region farther south $(\mathrm{n}=5,10 \%)$, or farther north than the head feather $(\mathrm{n}=10,21 \%)$.

\section{DISCUSSION}

The present study provides evidence that the 3 main regions used by king eiders in the Bering Sea can be distinguished based on $\delta^{13} \mathrm{C}$ and $\delta^{15} \mathrm{~N}$ of feathers grown in these regions. A spatial pattern of $\delta^{13} \mathrm{C}$ and $\delta^{15} \mathrm{~N}$ has been shown to exist for sediments (Naidu et al. 2000), benthic organisms (Dunton et al. 1989), zooplankton (Schell et al. 1998), and king eider flight feathers (Knoche et al. 2007) in the Bering and Chukchi Seas. There is, however, substantial overlap among the 3 regions used by king eiders in both $\delta^{13} \mathrm{C}$ and $\delta^{15} \mathrm{~N}$ of feathers, and we suggest that both elements are required to accurately assign feathers of unknown origin to a specific region. Previous approaches of feather geographic assignment of king eiders using only $\delta^{15} \mathrm{~N}$ (Mehl et al. 2005) would have assigned $20 \%$ of our samples to the Atlantic Ocean, which is an extremely unlikely wintering region for birds from our study area (Phillips et al. 2006, Oppel et al. 2008). Besides using 2 isotopic dimensions, the application of an assignment probability threshold also increased the accuracy of our geographic assignments. Mehl et al. (2004) did not exclude feathers with ambiguous assignment probabilities, and may have erroneously assigned 4 of $6 \mathrm{king}$ eiders with $<75 \%$ assignment probability to wintering areas in a different ocean (Mehl et al. 2004). The choice of an appropriate assignment probability threshold depends on the number of distinct regions examined (Wunder et al. 2005) and requires careful consideration. While choosing a higher threshold (e.g. >90\% probability) will increase the accuracy of assignments, it will decrease the number of samples that can be assigned with above-threshold assignment probability (Wunder et al. 2005, Rocque et al. 2006). In the present study, $13 \%$ of all samples could not be accurately assigned to any of the 3 regions. This trade-off between accuracy and the proportion of samples retained for inference needs to be carefully considered in studies applying the approach presented here.

Claws can be a useful tissue to trace king eiders to wintering grounds, but the amount of information gained in comparison with head feathers is limited. By using claw data we found that in $10 \%$ of birds, head feathers were likely grown before the birds migrated from molting to wintering regions. The use of claws as an alternative to feathers is currently handicapped by limited information on claw growth rates. In $20 \%$ of birds the claw was assigned to an area farther north than the head feather, indicating that the sampled portion of the claw may have grown during spring migration and not during winter. Interpreting potential causes for discrepancies between feather and claw assignments is complicated by our lack of knowledge of the time of tissue synthesis, and a better understanding of claw growth rates is clearly needed. Experimen- 
tal data on claw growth rates and discrimination ratios would be useful before isotope ratios of claw tips alone can be reliably employed to infer geographic origin at certain times of the annual cycle (Bearhop et al. 2003).

The isotopic composition of feathers and claws represents the isotopic composition of the bird's diet during the time of tissue growth plus some enrichment factor (Mizutani et al. 1992). The diet of king eiders in the Bering Sea is poorly known, but likely consists of a variety of benthic and epibenthic macro-invertebrates (Frimer 1997, Suydam 2000, Merkel et al. 2007b). Potential prey items in the southeastern Bering Sea range from -19 to $-17 \%$ in $\delta^{13} \mathrm{C}$ and 12 to $17 \%$ in $\delta^{15} \mathrm{~N}$ (Dunton et al. 1989). This is consistent with the range of king eider feathers we assigned to this region $\left(\delta^{13} \mathrm{C}\right.$ : -18 to $-16 \%$; $\delta^{15} \mathrm{~N}$ : 16 to $20 \%$ ) if we apply general diet-feather discrimination factors of $+1.4 \%$ for $\delta^{13} \mathrm{C}$ and $+3.6 \%$ for $\delta^{15} \mathrm{~N}$ (Becker et al. 2007). Similarly, feather isotope ratios from the northern Bering Sea show a range of 13.5 to $16 \%$ in $\delta^{15} \mathrm{~N}$, which agrees well with the $\delta^{15} \mathrm{~N}$-range (9.5 to $11.5 \%$ ) of the most common bivalves and crustaceans in this region (Lovvorn et al. 2005). Potential prey items in the northern Bering Sea show a wide range in $\delta^{13} \mathrm{C}(-22$ to $-17 \%$, Lovvorn et al. 2005), and this offers an explanation for the wide $\delta^{13} \mathrm{C}$ range we found in king eider feathers grown in this region.

Isotopic differences among the 3 wintering regions could result from differences in diet composition and/or a different structure of respective food webs. Little is known about king eider diet composition in the Bering Sea (Suydam 2000). However, the isotopic composition of benthic prey differs across the Bering Sea partly due to differences in the importance of particulate organic matter as a primary nutrient source for benthic organisms (Dunton et al. 1989, Hobson et al. 1995, Lovvorn et al. 2005). The depletion of $\delta^{13} \mathrm{C}$ in feathers grown along the coast of Alaska could result from freshwater inflow from rivers, as freshwater is depleted in ${ }^{13} \mathrm{C}$ compared to seawater (Peterson \& Fry 1987). This could potentially lead to misclassifications if birds in other regions molt feathers in the immediate vicinity of freshwater discharge areas. Overall, differences we report for feathers are consistent with currently known isotopic patterns across the Bering Sea, but more research is required to determine causes of large-scale regional differences in isotope ratios of higher trophic level consumer tissues.

Based on geographic assignment of head feathers we estimated fairly equal proportions of king eiders wintering in the 3 regions of the Bering Sea. This result is similar to the wintering distribution of king eiders tracked via satellite transmitters from the same breeding location (Phillips et al. 2006, Oppel et al. 2008). Together these studies support the conclusion that king eiders breeding in Alaska winter in different areas of the Bering Sea, and that migratory connectivity is diffuse. The approach presented here offers a simple and cheap alternative to support conclusions derived from satellite telemetry, and thus increases confidence in population inference (Lindberg \& Walker 2007).

Results presented here for head feathers might also be applicable to other feathers grown in the same regions in the Bering Sea, as diet-feather discrimination factors are similar for different feather tracts (Mizutani et al. 1992, Thompson \& Furness 1995, Bearhop et al. 1999). At the population level, king eiders use the same regions in the Bering Sea in which they winter for their annual flight feather molt (Phillips et al. 2006). Therefore, $\delta^{13} \mathrm{C}$ and $\delta^{15} \mathrm{~N}$ of flight feathers such as primaries could be used to assign king eiders to a molting region in the Bering Sea using our DFA model. We evaluated this approach by applying our model to an external data set of isotope ratios from king eider primaries collected in 2003 (Knoche et al. 2007). We were able to reliably (>75\%) assign 11 out of 12 feathers $(92 \%)$, and 10 of these feathers (90\%) were correctly assigned to the region where the bird was recorded during wing molt 1 yr later. This shows that our model performs well with data from a different feather type.

The use of multiple tissues such as primaries, head feathers, and claws from the same bird captured on breeding grounds may enable an assessment of the migration strategy of an individual by assigning tissues to their respective molting and wintering regions (Yerkes et al. 2008). Our model provides a suitable framework for all feathers grown in the Bering Sea. However, some female king eiders may molt flight feathers in freshwater ponds on breeding grounds (Knoche 2004), and some females breeding in the western Canadian Arctic may molt flight feathers in the eastern Beaufort Sea (2 of 51 birds tracked with satellite transmitters, D. L. Dickson unpubl. data). Both freshwater ecosystems and the eastern Beaufort Sea are known to be relatively depleted in ${ }^{13} \mathrm{C}$ (Peterson \& Fry 1987, Dunton et al. 1989, Schell et al. 1998), and feathers grown there are distinct from feathers grown in the Bering Sea. We urge researchers and managers to carefully consider the migration and molt schedules of their study species before using our model. Feathers grown outside the Bering Sea should not be classified with the discriminant function model presented here.

We demonstrated that king eider tissues can be assigned to a region in the Bering Sea with high accuracy. This approach could also be applied to a variety of birds and mammals using the Bering Sea and feeding on similar prey as king eiders, such as other sea ducks, loons, gulls, walrus Odobenus rosmarus, or 
gray whales Eschrichtius robustus. We recommend that the model presented here be validated by analyzing prey items across large spatial and temporal scales to establish isotopic baselines of the geographic regions in the Bering Sea (Inger \& Bearhop 2008). Isotope analysis of sea duck feathers can then be used to estimate remote molting and wintering locations and explore whether breeding performance varies for sea ducks wintering in different regions. Knowing wintering regions for sea ducks is essential for evaluating causes of changes in population size or developing management actions to recover populations.

Acknowledgements. This study was funded by the Coastal Marine Institute (University of Alaska, Fairbanks), Minerals Management Service, and U.S. Geological Survey. Further financial and technical support was provided by the U.S. Fish and Wildlife Service, North Slope Borough from NPR-A Impact Funds from the State of Alaska's Department of Commerce, Community and Economic Development, U.S. Geological Survey (Alaska Cooperative Fish and Wildlife Research Unit), Institute for Arctic Biology (University of Alaska, Fairbanks), ConocoPhillips Alaska Inc., and German Academic Exchange Service. We thank C. Monnett, J. Gleason, and B. Anderson for input and technical assistance, and C. Rea and R. Suydam for logistical support. For assistance in trapping eiders we thank R. Bentzen, C. Latty, M. Miller, J. Rogalla, and J. Heathcote. S. Sekine, E. Boone, M. Miller, N. Haubenstock and T. Howe helped with sample preparation, processing, and data interpretation. We are very grateful to M. Knoche and L. Phillips, who initiated this project and provided inspiration and assistance throughout. D. L. Dickson shared information on satellite tracked birds, and R. P. Barry and R. Mundry offered assistance for data analysis. The manuscript benefited from thoughtful comments by D. Rocque, R. Suydam, E. Weiser, and E. C. Murphy. The use of trade, product, or firm names in this publication is for descriptive purposes only and does not imply endorsement by the U.S. Government.

\section{LITERATURE CITED}

Bearhop S, Thompson DR, Waldron S, Russell IC, Alexander G, Furness RW (1999) Stable isotopes indicate the extent of freshwater feeding by cormorants Phalacrocorax carbo shot at inland fisheries in England. J Appl Ecol 36:75-84

Bearhop S, Furness RW, Hilton GM, Votier SC, Waldron S (2003) A forensic approach to understanding diet and habitat use from stable isotope analysis of (avian) claw material. Funct Ecol 17:270-275

Bearhop S, Hilton GM, Votier SC, Waldron S (2004) Stable isotope ratios indicate that body condition in migrating passerines is influenced by winter habitat. Proc R Soc Lond B 271(Suppl 4):S215-S218

Becker $\mathrm{BH}$, Newman SH, Inglis S, Beissinger SR (2007) Diet-feather stable isotope (delta N-15 and delta C-13) fractionation in common murres and other seabirds. Condor 109:451-456

Bustnes JO, Erikstad KE (1988) The diets of sympatric wintering populations of common eider Somateria mollissima and king eider $S$. spectabilis in northern Norway. Ornis Fenn 65:163-168
Bustnes JO, Asheim M, Bjorn TH, Gabrielsen H, Systad GH (2000) The diet of Steller's eiders wintering in Varangerfjord, northern Norway. Wilson Bull 112:8-13

Dunton KH, Saupe SM, Golikov AN, Schell DM, Schonberg SV (1989) Trophic relationships and isotopic gradients among Arctic and sub-Arctic marine fauna. Mar Ecol Prog Ser 56:89-97

Frimer O (1997) Diet of moulting king eiders Somateria spectabilis at Disko Island, Greenland. Ornis Fenn 74: 187-194

> Gómez-Díaz E, González-Solís J (2007) Geographic assignment of seabirds to their origin: combining morphologic, genetic, and biogeochemical analyses. Ecol Appl 17: 1484-1498

Grebmeier JM, Overland JE, Moore SE, Farley EV and others (2006) A major ecosystem shift in the Northern Bering Sea. Science 311:1461-1464

> Hobson KA (1999) Tracing origins and migration of wildlife using stable isotopes: a review. Oecologia 120:314-326

> Hobson KA (2005) Stable isotopes and the determination of avian migratory connectivity and seasonal interactions. Auk 122:1037-1048

> Hobson KA, Ambrose WG, Renaud PE (1995) Sources of primary production, benthic-pelagic coupling, and trophic relationships within the Northeast Water Polynya: insights from $\delta^{13} \mathrm{C}$ and $\delta^{15} \mathrm{~N}$ analysis. Mar Ecol Prog Ser 128:1-10

> Inger R, Bearhop S (2008) Applications of stable isotope analyses to avian ecology. Ibis 150:447-461

Knoche MJ (2004) King eider wing molt: inferences from stable isotope analysis. MS thesis, University of Alaska, Fairbanks, AK

> Knoche MJ, Powell AN, Quakenbush LT, Wooller MJ, Phillips LM (2007) Further evidence for site fidelity to wing molt locations by king eiders: integrating stable isotope analyses and satellite telemetry. Waterbirds 30:52-57

> Lindberg MS, Walker J (2007) Satellite telemetry in avian research and management: sample size considerations. J Wildl Manag 71:1002-1009

Lovvorn JE, Richman SE, Grebmeier JM, Cooper LW (2003) Diet and body condition of spectacled eiders wintering in pack ice of the Bering Sea. Polar Biol 26:259-267

Lovvorn JR, Cooper LW, Brooks ML, De Ruyck CC, Bump JK, Grebmeier JM (2005) Organic matter pathways to zooplankton and benthos under pack ice in late winter and open water in late summer in the north-central Bering Sea. Mar Ecol Prog Ser 291:135-150

Madge S, Burn H (1988) Wildfowl: an identification guide to the ducks, geese and swans of the world. Christopher Helm, Bromley, Kent

Marra PP, Hobson KA, Holmes RT (1998) Linking winter and summer events in a migratory bird by using stable-carbon isotopes. Science 282:1884-1886

Mehl KR, Alisauskas RT, Hobson KA, Kellett DK (2004) To winter east or west? Heterogeneity in winter philopatry in a central-arctic population of king eiders. Condor 106: 241-251

> Mehl KR, Alisauskas RT, Hobson KA, Merkel FR (2005) Linking breeding and wintering grounds of king eiders: making use of polar isotopic gradients. J Wildl Manag 69: 1297-1304

> Merkel F, Jamieson S, Falk K, Mosbech A (2007a) The diet of common eiders wintering in Nuuk, Southwest Greenland. Polar Biol 30:227-234

> Merkel F, Mosbech A, Jamieson S, Falk K (2007b) The diet of king eiders wintering in Nuuk, Southwest Greenland, with reference to sympatric wintering common eiders. Polar Biol 30:1593-1597 
Mizutani H, Fukuda M, Kabaya Y (1992) C-13 and N-15 enrichment factors of feathers of 11 species of adult birds. Ecology 73:1391-1395

Naidu AS, Cooper LW, Finney BP, Macdonald RW, Alexander C, Semiletov IP (2000) Organic carbon isotope ratios $\left(\delta^{13} C\right)$ of Arctic Amerasian continental shelf sediments. Int $\mathrm{J}$ Earth Sci 89:522-532

Newton I (2006) Can conditions experienced during migration limit the population levels of birds? J Ornithol 147: 146-166

Norris DR, Marra PP, Kyser TK, Sherry TW, Ratcliffe LM (2004) Tropical winter habitat limits reproductive success on the temperate breeding grounds in a migratory bird. Proc R Soc Lond B 271:59-64

Norris DR, Wunder MB, Boulet M (2006) Perspectives on migratory connectivity. Ornithol Monogr 61:79-88

Oppel S, Powell AN, Dickson DL (2008) Timing and distance of king eider migration and winter movements. Condor 110:296-305

Peterson BJ, Fry B (1987) Stable isotopes in ecosystem studies. Annu Rev Ecol Syst 18:293-320

Phillips LM, Powell AN (2006) Evidence for wing molt and breeding site fidelity in king eiders. Waterbirds 29:148-153

Phillips LM, Powell AN, Rexstad EA (2006) Large-scale movements and habitat characteristics of king eiders throughout the nonbreeding period. Condor 108:887-900

Robertson G, Cooke F (1999) Winter philopatry in migratory waterfowl. Auk 116:20-34

Rocque DA, Ben-David M, Barry RP, Winker K (2006) Assigning birds to wintering and breeding grounds using stable

Editorial responsibility: John Piatt, Anchorage, Alaska, USA isotopes: lessons from two feather generations among three intercontinental migrants. J Ornithol 147:395-404

Royle JA, Rubenstein DR (2004) The role of species abundance in determining breeding origins of migratory birds with stable isotopes. Ecol Appl 14:1780-1788

Schell DM, Barnett BA, Vinette KA (1998) Carbon and nitrogen isotope ratios in zooplankton of the Bering, Chukchi and Beaufort seas. Mar Ecol Prog Ser 162:11-23

Suydam RS (2000) King eider (Somateria spectabilis). In: Poole A, Gill F (eds) The birds of North America, No 491. The Birds of North America, Philadelphia, PA

Suydam RS, Dickson DL, Fadely JB, Quakenbush LT (2000) Population declines of king and common eiders of the Beaufort Sea. Condor 102:219-222

Thompson DR, Furness RW (1995) Stable-isotope ratios of carbon and nitrogen in feathers indicate seasonal dietary shifts in northern fulmars. Auk 112:493-498

> Votier SC, Hatchwell BJ, Beckerman A, McCleery RH and others (2005) Oil pollution and climate have wide-scale impacts on seabird demographics. Ecol Lett 8:1157-1164

Webster MS, Marra PP, Haig SM, Bensch S, Holmes RT (2002) Links between worlds: unravelling migratory connectivity. Trends Ecol Evol 17:76-83

Wunder MB, Kester CL, Knopf FL, Rye RO (2005) A test of geographic assignment using isotope tracers in feathers of known origin. Oecologia 144:607-617

Yerkes T, Hobson KA, Wassenaar LI, Macleod R, Coluccy JM (2008) Stable isotopes $\left(\delta \mathrm{D}, \delta^{13} \mathrm{C}, \delta^{15} \mathrm{~N}\right)$ reveal associations among geographic location and condition of Alaskan northern pintails. J Wildl Manag 72:715-725

Submitted: March 28, 2008; Accepted: September 16, 2008

Proofs received from author(s): December 6, 2008 